\title{
A CASE OF DEEP VEIN THROMBOSIS DUE TO PROTEIN C, PROTEIN S DEFICIENCY AND HYPER- HOMOCYSTINAEMIA, A RARE GENETIC ABNORMALITIES
}

\author{
AHMED HOSSAIN ${ }^{1}$, QUAZI TARIKUL ISLAM ${ }^{2}$, UMME KULSUM MITU ${ }^{3}$, JAYANTA BANIK ${ }^{4}$, H.M. \\ MOSTAFISUR RAHMAN ${ }^{5}$, MAHMUD HASAN $^{6}$, A.B.M. GOLAM MOSTAFA ${ }^{7}$
}

\begin{abstract}
Approximately $80 \%$ of Deep Vein Thromboses (DVTs) are clinically asymptomatic, $20 \%$ of those that actually demonstrate signs and symptoms. DVT associated with protein $C$ and protein $S$ deficiencies are rare genetic abnormalities that cause thrombophilia and lead to thrombosis. Here we describe a case of 55-year old male who presented with recurrent DVT of left lower limb and eventually diagnosed as a case of DVT due to protein C and protein S deficiency with hyperhomocystinaemia.. The particular interest in this case report is that it is important to consider sceening for thrombophilia incase of DVT with uncertain aetiology.
\end{abstract}

Key words :Deep Vein Thromboses, protein $C$,protein $S$, thrombophilia, hyperhomocystinaemia

\section{Introduction}

Deep vein thromboses are a common and occasionally, fatal condition that are often clinically silent. whenever symptomatic, they can easily mimic or be masked by musculoskeletal conditions. Deficiencies of natural anticoagulants such as protein $\mathrm{C}$ and protein $\mathrm{S}$ leads to inherited thrombophilia which is defined as an enhanced inherited tendency to form venous thrombo-embolism without any apparent causes and tend to recur. ${ }^{1,2}$ In the early 1980 s protein $\mathrm{C}$ and protein $\mathrm{S}$ deficiencies were set as causes of inherited thrombophilia. Their prevalence in general population vary from $0.2 \%$ to $0.4 \%$ for protein $\mathrm{C}$ deficiency and $0.2 \%$ for protein $\mathrm{S}$ deficiency. ${ }^{3}$ Homocystein has been recognized as an independent risk factor for atherosclerosis, arterial \& venous thrombosis. ${ }^{4}$ Individuals with unexplai- ned venous thrombosis has demonstrated a greater than expected number of individuals with blood homocystein level above the $95^{\text {th }}$ percentile. ${ }^{5}$

Therefore, when any patient presents with deep venous thrombosis without precipitating conditions the screening for thrombophilia should be considered to find out the aetiology.

\section{Case Report}

A 55 years old gentleman, previously healthy male presented with a seven day history of gradual swelling and pain in the left lower limb. Pain was located over whole limb associated with redness, increased temperature and dilatation of the superficial veins. The pain was aggravated by sitting, immediately after walking for certain distance and rest being the only relieving factor. The patient's sleep was disturbed, particularly lying on the affected side. The patient's past medical history revealed similar event of swelling of his left leg 1 year ago which had been treated successfully. In the patient's history, there were no history of hypertension, recent major surgery, immobilization or occurrence of any serious medical conditions. On physical examination, he had no abnormalities except swollen left lower limb. Local examination of left lower limb revealed, skin redness, swelling engorged superficial veins,mild tenderness and increased temperature over whole limb. All lower extremity pulses were present and of equal volume in both sides and there were no digital ischemia.

On Investigation, Complete blood count and blood film reveals, WBC-6.25X109 /L Hematocrit-38.8\%,

1. Assistant Professor, Department of Medicine, Dhaka Medical College, Dhaka

2. Professor (PRL), Department of Medicine, Dhaka Medical College, Dhaka

3. Post graduate Trainee, Dept. of Medicine, Dhaka Medical College Hospital, Dhaka

4. Post graduate Trainee, Dept. of Medicine, Bangabandhu Sheikh Mujib Medical University, Dhaka

5. Assistant Registrar, ,Dept. of Medicine, Dhaka Medical College Hospital, Dhaka

6. Internal Medical Officer, Dept. of Medicine, Dhaka Medical College Hospital, Dhaka

7. Internal Medical Officer, Dept. of Medicine, Dhaka Medical College Hospital, Dhaka

Bangladesh J Medicine 2011; 22 : 27-29 
platelets-196X109/L, ESR:20 mm/1st hr, Hb-12.7 g/ dl. Urine analysis was negative for protein or red cells. S. Creatinine- $1.33 \mathrm{mg} / \mathrm{dl}$. Fasting Blood Sugar and Lipid profile were normal. Prothrombin time-14.2 sec on admission (control $12 \mathrm{sec}$ ).USG of whole abdomen showed thrombus in Inferior Vena Cava. Duplex Examination of left lower limb showed; deep venous thrombosis of If common femoral and popliteal segment. Protein C $-12.4 \%$ (70-100) and protein S: 25\% (60-130). Serum Homocysteine 26.96 micro mole /L.(5-15 micro mole)

\section{Discussion}

Deep venous thrombosis defined as a partial or complete occlution of a deep vein by thrombus, is a relatively uncommon yet important diagnosis in primary care practice. ${ }^{6,7}$ The common clinical presentation of the venous thrombo-embolic disease (VTE) is with deep vein thrombosis of the leg and / or pulmonary embolism. ${ }^{8}$ Risk factors of DVT include past history of deep vein thrombosis, pulmonary oedema, operative intervention, immobilization, trauma, neurological deficit, malignancies, sepsis, central venus catheter and hyper-coagulable state etc. ${ }^{9}$ The prothrombotic states are protein $\mathrm{C} \&$ protein $\mathrm{S}$ deficiency, activated protein $\mathrm{C}$ resistance, antithrombin III deficiency, elevated homocystiene level \& abnormal lipid profile. The antiphospholipid syndrome, thrombocythemia \& severe bacterial infection cause acquired hyper coagulable states. ${ }^{9-}$ 13 Homozygous homocystinaemia accounts for 1 in 335000 live births and is characterized by pre-mature vascular disease, thrombosis, mental retardation, skeletal abnormalities and lens disloca-tion. Heterozygous homocystinaemia is far more common, affecting up to $0.3-1 \%$ of the general populatnd is associated with recurrent deep venous thromboembolism. ${ }^{14}$ Congenital protein C \& protein $\mathrm{S}$ deficiencis are inherited disorders $\&$ the prevalence of protein $\mathrm{C}$ deficiency is 1 in $300 \&$ that of protein $\mathrm{S}$ deficiency is less frequent than 1 in 1000 . So the possibility of someone inheriting both deficiencies together is less than 1 in 300000, extremely rare. ${ }^{15}$ Protein $\mathrm{C}$ and protein $\mathrm{S}$ systems are the major regulatory system of haemostasis. These proteins are vitamin $\mathrm{K}$ dependent proenzymes synthesized in the liver and become activated after binding to thrombinthrombomodulin complex on the surface of endothelial cells. Thus activated protein $\mathrm{C}$ inhibits factors VIIIa \& Va. Here protein S acts as a cofactor $\&$ exhibiting their anticoagulant property. Acquired causes of these deficiencies are seen in liver disease, DIC, therapy with L-asparaginase, Coumarin \& severe infections etc. ${ }^{16}$ These deficiencies commonly present with DVT, account for nearly $90 \%$ of all venous thrombotic episodes \& Pulmonary embolism. \& thrombosis in other venous sides about $5 \%$ of cases. Chronic sequelae can be extremely debilitating because of the post-thrombotic syndrome that can affect up to $20 \%$ of the patients. ${ }^{17}$ Recurrent DVT can occur with. or without thrombophilic conditions , the highest risk being in the first 6 month. ${ }^{18}$ Homocysteinaemia has been identified as an independent risk factor for coronary artery disease, peripheral vascular disease and thrombosis. Heterozygous homocysteina- emia has been recognized in up to $25 \%$ of patients with recurrent venous thrombosis. ${ }^{14,19}$

Doppler ultrasonography and venography although being regarded as the diagnostic "gold standard",require a high level of training for the operator in order to be reliable.Venography is also an invasive procedure.Recently, the diagnosis of DVT has been improved by performing a probability test using the measurement of D-dimer levels (the products of fibrin degradation that increase with venous thromboembolism). ${ }^{20}$

It is often make a fundamental error by testing for protein $\mathrm{C} \& \mathrm{~S}$ deficiency when a patient is taking Coumarin (warfarin) or when they have had recent thrombotic event, as both of these causes protein $\mathrm{C}$ $\& \mathrm{~S}$ to be temporarily decreased So to confirm this deficiency, the patient must be off Coumarin for at least 14 days \& must not have an active clotting episode in progress. So to confirm, we should repeat the test after 12 weeks \& also testing the patient's first-degree relatives. ${ }^{15}$

Hyperhomocysteinaemia appears to increa-and measurement of total fasting homocysteine levels alone can be misleading as it appears to misclassify $40 \%$ of patients. Conclusive results can be obtained using a moresensitive test by measurement of serum homocysteine levels before and after oral methionine loading. 19

The goals of treatment for DVT include halting clot formation \& preventing recurrence of thrombi \& PE. About $30 \%$ of DVT patient have a thrombophilia. The main stay of treatment was unfractionated heparin followed by warfarin. Out patient anticoagulant therapy is recommended for 3 to 6 month for VTE \& for more than 12 month for recurrent VTE. ${ }^{21}$

\section{Conclusion}

So whenever a DVT of uncertain aetiology is suspected, it might have benefit from hypercoagulability testing because it is important to focus on inherited blood clotting problems. Except in 
the most severe cases, inherited problems are usually enough to cause DVT or pulmonary embolism on their own but this problems contribute to clot only when they are combined with environmental factors which activates the body's blood clotting machinery.If an inherited thrombophilia is diagnosed further screening and possible identification of other family members would lead to avoidance of known secondary risk factors and subsequent thrombo-embolic manifestations.

\section{References:}

1. Simioni P.Who should be tested for thrombophilia? Curr Opin Hematol. 2006; 13(5): 337-43

2. Pabinger I. Thrombophilia and its impact on pregnancy.Thromb Res. 2009; 123 Suppl 3:S16-21.

3. Whilatch NL, Orfel TL. Thrombophilias :When should we test and how does it help? Seminars in Respiratory and Critical Care Medicine.2008;29(1):27-36

4. Mayer E, Jacobsen D, Robinson K.Homocysteine and coronary atherosclerosis. J Am Coll Cardiol 1996;27:517-527.

5. Heijer M, Koster T, Blom H Hyperhomocysteinemia as a risk factor for deep-vein thrombosis. N Engl J Med 1996;334:759-762.

6. Anderson FA, Wheeler HB, Goldberg RJ. A population-based perspective of the hospital incidence and case fatality rates of deep vein thrombosis and pulmonary embolism: the Worcester DVTstudy.Arch Intern Med 1991;151:933-3

7. Silverstein MD, Heit JA, Mohr DN. Trends in the incidence of deep vein thrombosis and pulmonary embolism: a 25-year population-based study. Arch Intern Med 1998,158:585-93

8 J.I.O. Craig, D.B.L. Mc Clelland, H.G. Watson.Blood disease. In : Nicki R. colledge, Brain R.Walker, Stuart H. Ralston, editors. Davidson's Principles and Practice of Medicine. $21^{\text {st }}$ ed. Philadelphia, USA: Churchill Livingstone;2010. p.985-1051.

9 Miyata $\mathrm{T}$, Sakata $\mathrm{T}$, Yasumuro $\mathrm{Y}$, Okamura $\mathrm{T}$, Katsumi A, Saito $\mathrm{H}$, et al. Genetic analysis of protein $\mathrm{C}$ deficiency in nineteen Japanese families:five recurrent defects can explain half of the deficiencies. Thromb Res 1998;92:181-87.

10 Saxena R, Mohanthy S, Srivastava A, Choudhry VP, Kotwal J. Pathogenic factors underlying juveniledeep vein thrombosis in Indians. Eur $\mathrm{J}$ Hemat 1999;63: 26-28.
11 Bonduel M, Hepner M, Sciuccati G, Torres AF, Pieroni G, Frontroth JP,et al. Prothrombotic abnormalities in children with venous thromboemboLism. J Pediatr Hemtol Oncol 2000;22:66-72

12 David M, Andre M. Venous thromboembolic complications in children. J Pediatr 1993; 123: 337-346.

13 Gerson WT, Dickerman JD, Bovil EG, Golden E. Severe acquired protein 'C' deficiency in purpura fulminans associated with disseminated intravascular coagulation :Treatment with protein "C" concen-trate.Pediatrics 1993;91:418-421.

14. Rodgers GM.Thrombosis and antithro- mbotic therapy. In:LeeGR, Foerster J,Lukens J,Paraskev F, Greer JP, Rodgers GM, et al. Wintrobe's Clinical Hematology. Gizza, Egypt: Williams \& Wilkins, 1999; $2: 1$

15. Douketis JD, Berger PB, Dunn AS, The perioperative management of antithrombotic therapy: American College of Chest Physicians Evidence-Based Clinical Practice Guidelines (8th edition). Chest 2008;133:299S-340S

16. Hilgartner MW, Corrigan JJ Jr. Coagulation disorders. In: Miller DR, Baehner RL, Blood Diseases of Infancy and Childhood. 7th edn. Philadelphia: Mosby; 1995. p. 971-975

17. Lijfering M, Veeger NJGM, Middeldorp S, Hamulyak $\mathrm{K}$, Prins $\mathrm{MH}$, Buller $\mathrm{HR}$, et al. A lower risk of recurrent venous thrombosis in women compared with men is explained by sex-specific risk factors at time of first venous thrombosis in.thrombophilic families.Blood.2009; 114(10): 2031- 2036.

18. Hansson PO, Sorbo J, Eriksson H. Recurrent venous thromboembolism after deep vein thrombosis: incidence and risk factors.Arch Intern Med.2000; 160: 769-74.

19. Bostom AG, Jacques PF, Nadeau MR. Post methionine load hyperhomocystein-emia in persons normal fasting total plasma homocysteine.Initial results from the NHLBI Family Heart Study. Atherosclerosis 1995;116:147-51

20. Hull RD, Stein PD, Ghali WA, Corunz J. Diagnostic algorithms for deep vein thrombosis: Work in progress. Am J Med 2002; 113(8): 687-8

21. Ramzi DW, Leeper KV. DVT and pulmonary embolism: part I: diagnosis. Am Fam Physician. 2004; 69: 2829-36. 